\title{
Short-term effects of air pollution on exacerbations of allergic asthma in Užice region, Serbia
}

\author{
Gordana Kovačević ${ }^{1}$, Vesna Tomić-Spirićc ${ }^{2,3}$, Jelena Marinkovićc ${ }^{4}$, Slavenka Jankovićc ${ }^{5}$, Andja Ćirkovićc ${ }^{4}$ \\ Ana Milošević Djerićc ${ }^{1}$ Miloš Erić ${ }^{6}$, Janko Jankovićc ${ }^{7}$ \\ ${ }^{1}$ General Hospital Užice, Užice, Serbia \\ ${ }^{2}$ Faculty of Medicine, University of Belgrade, Belgrade, Serbia \\ ${ }^{3}$ Clinic of Allergology and Immunology, Clinical Centre of Serbia, Belgrade, Serbia \\ ${ }^{4}$ Institute of Medical Statistics and Informatics, Faculty of Medicine, University of Belgrade, Belgrade, Serbia \\ Institute of Epidemiology, Faculty of Medicine, University of Belgrade, Belgrade, Serbia \\ ${ }^{6}$ Faculty of Economics, Finance and Administration, Metropolitan University, Belgrade, Serbia \\ ${ }^{7}$ Institute of Social Medicine, Faculty of Medicine, University of Belgrade, Belgrade, Serbia
}

Adv Dermatol Allergol 2020; XXXVII (3): 377-383

DOI: hhttps://doi.org/10.5114/ada.2020.96254

\begin{abstract}
Introduction: Many time-series studies have shown a positive association between air pollution and asthma exacerbation. However, till now only one study in Serbia has examined this relationship.

Aim: To examine the associations between air pollution and asthma emergency department (ED) visits in the Užice region, Serbia.

Material and methods: A time-stratified case-crossover design was applied to 424 ED visits for asthma exacerbation that occurred in the Užice region, Serbia, in 2012-2014. Data about ED visits were routinely collected in the Užice Health Centre. The daily average concentrations of particulate matter $\left(\mathrm{PM}_{2.5}\right.$ and $\left.\mathrm{PM}_{10}\right)$, sulphur dioxide $\left(\mathrm{SO}_{2}\right)$, nitrogen dioxide $\left(\mathrm{NO}_{2}\right)$, and black carbon $(\mathrm{BC})$ were measured by automatic ambient air quality monitoring stations. Odds ratios and their corresponding 95\% confidence intervals were estimated using conditional logistic regression adjusted for the potential confounding influence of weather variables (temperature, humidity and air pressure). Results: Statistically significant associations were observed between ED visits for asthma and 3-day lagged exposure to $\mathrm{BC}(\mathrm{OR}=3.23 ; 95 \% \mathrm{Cl}: 1.05-9.95)$, and between $\mathrm{ED}$ visits for asthma with coexisting allergic rhinitis and 0-day lag exposure to $\mathrm{NO}_{2}(\mathrm{OR}=1.57 ; 95 \% \mathrm{Cl}: 0.94-2.65)$, 2-day lag exposure to $\mathrm{SO}_{2}(\mathrm{OR}=1.97 ; 95 \% \mathrm{Cl}: 1.02-3.80)$, and 3-day lag exposure to $\mathrm{PM}_{10}(\mathrm{OR}=2.38 ; 95 \% \mathrm{Cl}: 1.17-4.84)$.

Conclusions: Exposure to ambient air pollution in the Užice region increases the risk of ED visits for asthma, particularly during the heating season.
\end{abstract}

Key words: air pollution, allergic asthma, emergency department visits, case-crossover design, Serbia.

\section{Introduction}

The health effects of air pollution are increasingly recognized as a major public health concern. Previous studies that were carried out in major world cities proved the harmful effects of air pollutants on the course and prognosis of acute and chronic diseases among adults and children [1-3]. Estimates of the health impacts attributable to exposure to particulate matter (PM) with an aerodynamic diameter of $2.5 \mu \mathrm{m}$ or less $\left(\mathrm{PM}_{2.5}\right)$, ozone $\left(\mathrm{O}_{3}\right)$, and nitrogen dioxide $\left(\mathrm{NO}_{2}\right)$ concentrations in 2015 , were responsible for about 518700 premature deaths originating from long-term exposure in 41 European countries [4]. The epidemiological evidence relating short-term exposure with particulate matter with an aerodynamic diameter of $10 \mu \mathrm{m}$ or less $\left(\mathrm{PM}_{10}\right)$, and related metrics: black smoke (BS), black carbon (BC) and total suspended particles, with health effects is substantial [5]. Recently published systematic review and meta-analysis of 110 time series studies have found evidence for adverse health effects of short-term exposure to $\mathrm{PM}_{25}$ across a range of important health outcomes and diseases with

Address for correspondence: Janko Janković, Institute of Social Medicine, Faculty of Medicine, University of Belgrade, Belgrade, Serbia, phone: +381 112643 830, cell: +381 63 7767-839, fax: +381 11 2659-533, e-mail: drjankojankovic@yahoo. Received: 27.11.2018, accepted: 12.12.2018. 
a considerable variation between different regions of the world [6].

Special attention is focused on the respiratory system, which is the first point of contact with air pollutants. The impact of air pollution on chronic respiratory diseases, such as chronic obstructive pulmonary disease and asthma is well documented [7-9]. The harmful effects of principle air pollutants $\left(\mathrm{PM}, \mathrm{O}_{3}, \mathrm{CO}\right.$ and $\left.\mathrm{NO}_{2}\right)$ on the exacerbation of asthma, as well as respiratory morbidity and mortality in asthma patients are confirmed by epidemiological studies [10-12].

The global increase in the prevalence of allergic diseases is of great concern, especially in developing countries [13] and strong epidemiological evidence supports a relationship between air pollution and exacerbation of asthma and other allergic diseases [14].

Although the global problem of air pollution is recog nized worldwide, there are only a few published studies on the effects of air pollution on human health in Serbia $[15,16]$.

\section{Aim}

The aim of this study was to assess the short-term effect of air pollutants $\left(\mathrm{NO}_{2}, \mathrm{SO}_{2}, \mathrm{PM}_{2.5}, \mathrm{PM}_{10}\right.$, and $\left.\mathrm{BC}\right)$ concentrations on the exacerbation of the allergic bronchial asthma alone or asthma with coexisting allergic rhinitis $(A R)$ in the Užice region, Serbia.

\section{Material and methods}

\section{Study area}

The study was carried out over a 2-year period, from $1^{\text {st }}$ July 2012 to $30^{\text {th }}$ June 2014 in the Zlatibor District, Serbia (Figure $1 \mathrm{~A}$ ). The main city of the region is Užice with 78040 inhabitants [17], located in the latitude of $43^{\circ} 51^{\prime} \mathrm{N}$ and the longitude of $19^{\circ} 50^{\prime} \mathrm{E}$. It is situated on both sides of the river Đetinja, with average elevation of $411 \mathrm{~m}$ above the sea level, surrounded by the Dinaric mountains Zlatibor, Tara and Zlatar. Besides the city of Užice (including Sevojno), two other surrounding municipalities, Čajetina with 14745 inhabitants, and Kosjerić with 12090 inhabitants [17] were included in this study. It is worth noting that there are three different climates in this region, from moderate-continental to mountain and high-mountain (sub-alpine and alpine) climate. While Užice and Sevojno are centres of heavy industry, the mountain Zlatibor, thanks to the specific continental and Mediterranean air currents, a so-called wind rose, is considered an air spa suitable for the treatment and recovery from many diseases, including asthma. Considering the above, the chosen geographical area is extremely interesting for the assessment of the relationship between air pollution and health.

The study was approved by the Užice Hospital Ethics Committee.

\section{Study population}

We obtained routinely collected data of emergency department (ED) visits for allergic asthma from the Užice Health Centre, either from the EDs (ambulances or home care) in Užice, Sevojno, and Kosjerić or from a general hospital in Užice. A medical doctor reviewed the ED records. The admission date, age, gender, place of residence, and ED diagnosis were considered for each patient. The inclusion criteria were: adults aged 18 years and older with the diagnosis of allergic asthma (International Classification of Diseases, $10^{\text {th }}$ revision, code J.45.0) or asthma with coexisting allergic rhinitis (AR). Patients who experienced worsening due to respiratory infections or asthma types other than allergic asthma were excluded from the study.

\section{Air pollution, pollen and weather data}

The daily average concentrations of air pollutants $\left(\mathrm{SO}_{2}, \mathrm{NO}_{2}, \mathrm{PM}_{2.5}, \mathrm{PM}_{10}\right.$ and $\left.\mathrm{BC}\right)$ in micrograms per cubic meter $\left(\mu \mathrm{g} / \mathrm{m}^{3}\right)$ were measured by three automatic ambient air quality monitoring stations located in Užice, Sevojno, and Kosjerić (Figure 1 B). The concentrations were measured on the event day (0), on the previous day $(-1), 2$ days before $(-2)$ and 3 days before $(-3)$. Registered daily values of each air pollutant were average levels from all the stations, in order to assess the global environmental situation of the city and its surrounding.

The $\mathrm{SO}_{2}$ concentration was determined by the spectrophotometric method, while the concentration of $\mathrm{NO}_{2}$ was obtained by chemiluminescence detection. The PM monitor based on beta-ray attenuation was used to measure the concentrations of both $P M_{2.5}$ and $P M_{10}$. The BCP (black carbon particles) concentration was measured with reflectometers.

The daily meteorological dataset (temperature, relative humidity, and surface air pressure), as well as air allergen data (daily tree, grass, and weed pollen concentrations) were obtained from the automatic meteorological station located at Zlatibor [18]. The following pollens were detected: Pinaceae, Betulaceae, Poaceae, Plantago spp., Urticaceae and Asteraceae.

\section{Statistical analysis}

A time-stratified case-crossover design was used to assess the risk of ED admissions for asthma alone and asthma with coexisting AR based on exposure to various air pollutants.

The degree of association between different environmental variables (air pollutants, pollens, temperature, humidity and air pressure) was tested by nonparametric Spearman's rank correlation.

The multivariable conditional logistic regression models were applied as suitable for the explained design, aim and the type of data. Every seventh day before and after the event day was considered a control. 


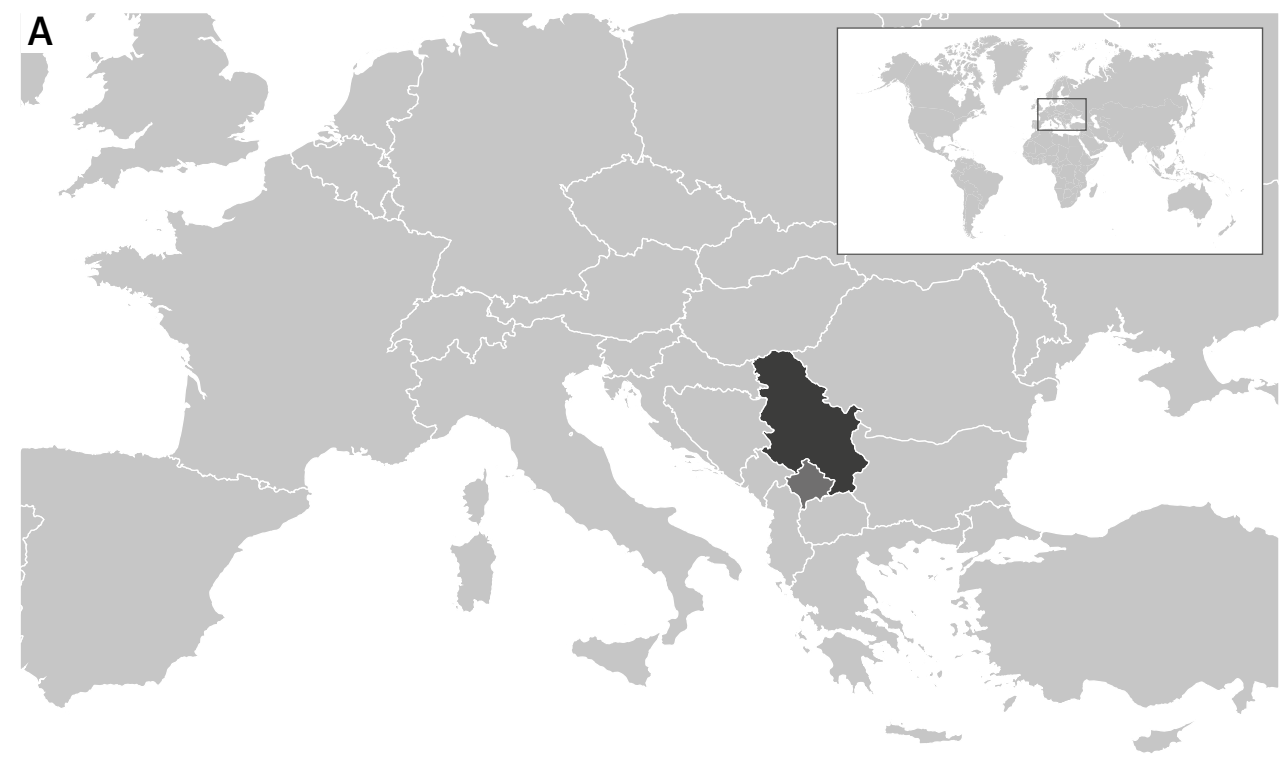

Lagged values were created for all models to assess an early effect: immediate (the event day, lag 0), and delayed (previous 3 days of exposure, lag 1, 2, and 3, respectively). The models were defined for each of the pollutants $\left(\mathrm{NO}_{2}, \mathrm{SO}_{2}, \mathrm{PM}_{2.5}, \mathrm{PM}_{10}, \mathrm{BC}\right)$ for lags $0,1,2$, and 3 , for patients with asthma alone and asthma with coexisting AR. To control potential confounding factors all models included daily weather variables (temperature, humidity and air pressure on lag 0 ). The results of the analyses were expressed as odds ratios (ORs) with their accompanying 95\% confidence intervals (Cls). The ORs were calculated in relation to air pollution concentration based on the daily mean level of each air pollutant presented by the third quintile in the way when the first or fifth quintile was the referent category.

A value of $p<0.05$ was considered statistically significant. Statistical analysis was performed using SPSS statistical software (SPSS for Windows, release 21.0, SPSS, Chicago, IL).

\section{Results}

A total of 424 ED asthma visits (179 asthma alone and 245 asthma with AR) occurred during the study period (Table 1). Most of these visits (28.1\%) concerned young adults aged $18-34$ years. There were more visits among females (67.2\%) and during the heating season (77.8\%), while no statistically significant difference was seen between spring/summer and autumn/winter seasons.

Table 2 provides summary statistics for air pollutants, pollens and weather variables. During the study period, concentrations of $\mathrm{NO}_{2}$ and $\mathrm{SO}_{2}$ remained below the permitted daily limit values $\left(85 \mathrm{\mu g} / \mathrm{m}^{3}\right.$ for $\mathrm{NO}_{2}$ and $125 \mathrm{\mu g} / \mathrm{m}^{3}$ for $\mathrm{SO}_{2}$ ), whilst daily concentrations of $\mathrm{PM}_{10}$ and $\mathrm{BC}$ exceeded permitted limit values $\left(50 \mathrm{\mu g} / \mathrm{m}^{3}\right.$ for $\mathrm{PM}_{10}$ and

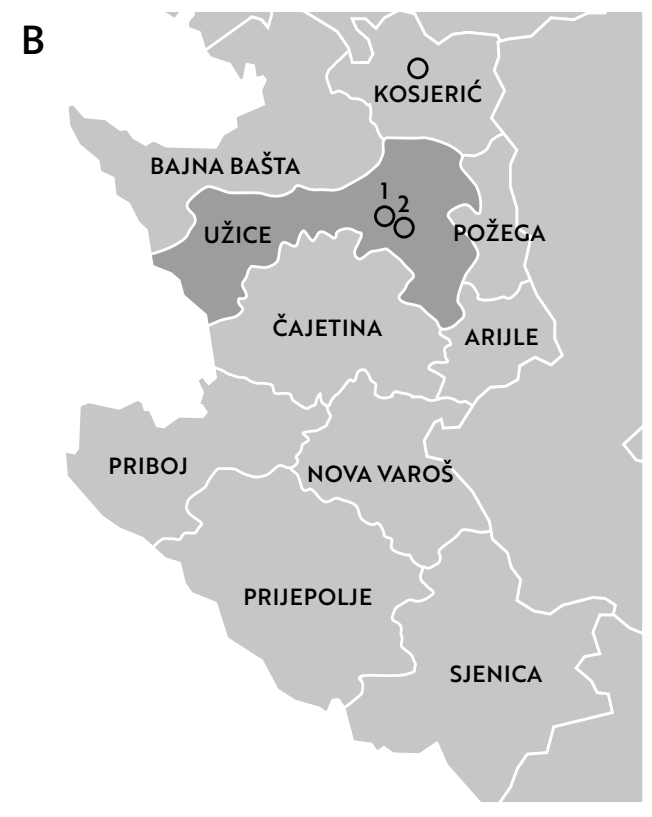

Figure 1. Location of Serbia in Europe (A) and the Zlatibor District with the location of air quality and meteorological monitoring stations (B)

$50 \mathrm{\mu g} / \mathrm{m}^{3}$ for $\mathrm{BC}$ ) proposed by the national Regulation on monitoring conditions and air quality requirements.

Correlations between air pollutants, pollens and weather conditions are shown in Table 3.

Air pollutants were all positively correlated with each other $(\rho=0.24-0.83)$. The highest correlation was seen between $\mathrm{PM}_{2.5}$ and $\mathrm{PM}_{10}(\rho=0.83)$, and between $\mathrm{PM}_{10}$ and $\mathrm{BC}$ $(\rho=0.75) . \mathrm{NO}_{2}$ was moderately correlated with particulates $(\rho=0.37-0.46)$. There was a weak correlation between $\mathrm{SO}_{2}$ and the other air pollutants $(\rho=0.24-0.33)$. All pollens were weak-moderately and positively correlated between each 
Table 1. Number (\%) of emergency department visits for asthma by age groups, sex and season in the Užice region, Serbia (2012-2014)

\begin{tabular}{lccc}
\hline Characteristic & $\begin{array}{c}\text { Asthma } \\
\text { alone }\end{array}$ & $\begin{array}{l}\text { Asthma } \\
\text { with AR }\end{array}$ & Total \\
\hline Total visits & $179(100)$ & $245(100)$ & $424(100)$ \\
\hline Age group: & $44(24.6)$ & $75(30.6)$ & $119(28.1)$ \\
\hline $18-34$ & $26(14.5)$ & $52(21.2)$ & $78(18.4)$ \\
\hline $35-44$ & $32(17.9)$ & $47(19.2)$ & $79(18.6)$ \\
\hline $45-54$ & $36(20.1)$ & $42(17.1)$ & $78(18.4)$ \\
\hline $55-64$ & $41(22.9)$ & $29(11.8)$ & $70(16.5)$ \\
\hline$\geq 65$ & & & \\
\hline Gender: & $52(29.1)$ & $87(35.5)$ & $139(32.8)$ \\
\hline Males & $127(70.9)$ & $158(64.5)$ & $285(67.2)$ \\
\hline Females & & & \\
\hline Season: & $90(50.3)$ & $116(47.3)$ & $206(48.6)$ \\
\hline Spring/summer & $89(49.7)$ & $129(52.7)$ & $218(51.4)$ \\
\hline Autumn/winter & & & \\
\hline Heating season*: & $36(20.1)$ & $58(23.7)$ & $94(22.2)$ \\
\hline Yes & $143(79.9)$ & $187(76.3)$ & $330(77.8)$ \\
\hline No & &
\end{tabular}

AR-allergic rhinitis. * 6 months' period, from $15^{\text {th }}$ October to $15^{\text {th }}$ April.

other $(\rho=0.15-0.62)$, and were negatively correlated with air pollutants ( $\rho$ ranged from -0.17 to -0.52 ).

Estimated adjusted odds ratios with $95 \% \mathrm{Cl}$ for ED visits for asthma alone and asthma with allergic rhinitis based on 1-3-day lagged exposure to air pollution are displayed in Table 4.
Statistically significant associations were observed between ED visits for asthma and 3-day lagged exposure to $\mathrm{BC}(\mathrm{OR}=3.23$; 95\% Cl: 1.05-9.95), and between ED visits for asthma with coexisting AR and 0-day lag exposure to $\mathrm{NO}_{2}(\mathrm{OR}=1.57 ; 95 \% \mathrm{Cl}: 0.94-2.65)$, 2-day lag exposure to $\mathrm{SO}_{2}(\mathrm{OR}=1.97 ; 95 \% \mathrm{Cl}: 1.02-3.80)$ and 3-day lag exposure to $\mathrm{PM}_{10}(\mathrm{OR}=2.38 ; 95 \% \mathrm{Cl}: 1.17-4.84)$.

\section{Discussion}

The present study analysed the impact of air pollution on ED visits for allergic asthma in the adult population of the Užice region. The results suggest a positive association between ambient exposure to $\mathrm{PM}_{10}, \mathrm{BC}, \mathrm{SO}_{2}$ and $\mathrm{NO}_{2}$ pollutants and $\mathrm{ED}$ visits for asthma. The highest association was with $\mathrm{BC}$ and $\mathrm{PM}_{10}$. The most immediate effects were seen for $\mathrm{NO}_{2}$, associated with the reportingday pollutant level.

PM, a complex, heterogeneous mixture whose composition changes in time and space, and depends on emissions from various sources, atmospheric chemistry and weather conditions, includes "fine particles" which are $2.5 \mu \mathrm{m}$ in diameter or less $\left(\mathrm{PM}_{2.5}\right)$ and "coarse particles" which have diameters between 2.5 and $10 \mu \mathrm{m}$ $\left(\mathrm{PM}_{10}\right)$ [19]. Many epidemiological studies have shown short-term harmful health effects of PM [5]. However, it is likely that not every PM component is equally important in causing health effects [20]. Combustion-related particles, known as black carbon (BC) particles, are thought to be more harmful to health than PM that is not generated by combustion [20]. Historical studies are based on $\mathrm{BS}$, but more recent studies use absorbance (Abs), BC or elemental carbon (EC) as exposure indicators [21]. The highest association in the current study occurred with

Table 2. Daily concentrations of air pollutants, pollen levels and weather variables in the Užice region, Serbia (2012-2014)

\begin{tabular}{|c|c|c|c|c|c|c|c|c|}
\hline \multirow[t]{2}{*}{ Pollutant } & \multirow[t]{2}{*}{ Median } & \multirow[t]{2}{*}{$\mathrm{IQR}$} & \multirow[t]{2}{*}{ Min. } & \multicolumn{4}{|c|}{ Percentiles } & \multirow[t]{2}{*}{ Max. } \\
\hline & & & & $20 \%$ & $40 \%$ & $60 \%$ & $80 \%$ & \\
\hline $\mathrm{NO}_{2} 24 \mathrm{~h}\left[\mu \mathrm{g} / \mathrm{m}^{3}\right]$ & 6.93 & 8.37 & 1.58 & 3.34 & 5.17 & 8.52 & 13.23 & 78.25 \\
\hline $\mathrm{SO}_{2} 24 \mathrm{~h}\left[\mu \mathrm{g} / \mathrm{m}^{3}\right]$ & 15.00 & 4.49 & 11.51 & 12.84 & 14.08 & 15.00 & 19.40 & 80.78 \\
\hline $\mathrm{PM}_{2.5} 24 \mathrm{~h}\left[\mu \mathrm{g} / \mathrm{m}^{3}\right]$ & 27.08 & 25.67 & 9.33 & 16.48 & 22.11 & 31.73 & 45.50 & 414.42 \\
\hline $\mathrm{PM}_{10} 24 \mathrm{~h}\left[\mu \mathrm{g} / \mathrm{m}^{3}\right]$ & 34.32 & 32.38 & 9.90 & 19.07 & 28.13 & 42.15 & 58.69 & 327.36 \\
\hline $\mathrm{BC} 24 \mathrm{~h}\left[\mu \mathrm{g} / \mathrm{m}^{3}\right]$ & 21.66 & 38.67 & 4.00 & 8.33 & 16.33 & 29.00 & 54.67 & 308.67 \\
\hline Tree pollens [grains/m³] & 0.00 & 3.00 & 0.00 & 0.00 & 0.00 & 1.00 & 4.00 & 503.00 \\
\hline Grass pollens [grains/m³] & 0.00 & 0.00 & 0.00 & 0.00 & 0.00 & 0.00 & 0.00 & 243.00 \\
\hline Weed pollens [grains/m³] & 0.00 & 2.00 & 0.00 & 0.00 & 0.00 & 0.00 & 5.00 & 370.00 \\
\hline Temperature $\left[{ }^{\circ} \mathrm{C}\right]$ & 16.20 & 15.27 & -6.67 & 5.80 & 13.02 & 18.79 & 24.23 & 36.23 \\
\hline Relative humidity (\%) & 58.30 & 34.43 & 11.53 & 38.23 & 48.53 & 64.83 & 78.13 & 98.80 \\
\hline
\end{tabular}


Table 3. Matrix of correlation coefficients* between air pollutants, pollen levels and weather variables in the Užice region, Serbia (2012-2014)

\begin{tabular}{|c|c|c|c|c|c|c|c|c|c|c|}
\hline Variable & $\mathrm{NO}_{2}$ & $\mathrm{SO}_{2}$ & $\mathrm{PM}_{2.5}$ & $\mathrm{PM}_{10}$ & $B C$ & $\begin{array}{c}\text { Tree } \\
\text { pollens }\end{array}$ & $\begin{array}{l}\text { Grass } \\
\text { pollens }\end{array}$ & $\begin{array}{l}\text { Weed } \\
\text { pollens }\end{array}$ & Temperature & Humidity \\
\hline $\mathrm{NO}_{2}$ & 1.00 & & & & & & & & & \\
\hline $\mathrm{SO}_{2}$ & 0.24 & 1.00 & & & & & & & & \\
\hline $\mathrm{PM}_{2.5}$ & 0.37 & 0.28 & 1.00 & & & & & & & \\
\hline $\mathrm{PM}_{10}$ & 0.39 & 0.31 & 0.83 & 1.00 & & & & & & \\
\hline$B C$ & 0.46 & 0.33 & 0.68 & 0.75 & 1.00 & & & & & \\
\hline Tree pollens & -0.20 & -0.18 & -0.37 & -0.39 & -0.27 & 1.00 & & & & \\
\hline Grass pollens & -0.25 & -0.17 & -0.41 & -0.45 & -0.47 & 0.30 & 0.30 & & & \\
\hline Weed pollens & -0.30 & -0.27 & -0.35 & -0.35 & -0.52 & 0.15 & 0.62 & 1.00 & & \\
\hline Temperature & -0.39 & -0.44 & -0.56 & -0.54 & -0.67 & 0.25 & 0.47 & 0.60 & 1.00 & \\
\hline Humidity & 0.29 & 0.29 & 0.33 & 0.28 & 0.41 & -0.31 & -0.35 & -0.42 & -0.77 & 1.00 \\
\hline
\end{tabular}

* Spearman correlation coefficients. All values are statistically significant. $\mathrm{NO}_{2}$ - nitrogen dioxide, $\mathrm{SO}_{2}-$ sulphur dioxide, $P M_{25}-$ particulate matter with an aerodynamic diameter of $2.5 \mu \mathrm{m}$ or less, $P M_{10}$ - particulate matter with an aerodynamic diameter of $10 \mu \mathrm{m}$ or less, $B C$ - black carbon.

Table 4. Adjusted odds ratios with 95\% confidence intervals for the relationship between exposure to outdoor air pollution and emergency department visits for asthma in the Užice region, Serbia (2012-2014)

\begin{tabular}{lcccccc}
\hline Asthma & Lags & $\mathrm{NO}_{2}$ & $\mathrm{SO}_{2}$ & $\mathrm{PM}_{2.5}$ & $\mathrm{PM}_{10}$ & $\mathrm{BC}$ \\
\hline $\begin{array}{l}\text { Alone } \\
(N=179)\end{array}$ & 0-day lag & $1.23(0.66-2.29)$ & $0.83(0.34-1.99)$ & $1.28(0.58-2.85)$ & $1.01(0.53-1.93)$ & $1.35(0.44-4.18)$ \\
\cline { 2 - 6 } & 1-day lag & $1.30(0.68-2.47)$ & $1.07(0.46-2.48)$ & $1.39(0.62-3.14)$ & $1.00(0.49-2.03)$ & $1.19(0.41-3.44)$ \\
\cline { 2 - 6 } & 2-day lag & $0.70(0.37-1.35)$ & $1.01(0.42-2.45)$ & $1.30(0.56-2.98)$ & $0.71(0.33-1.50)$ & $2.46(0.78-7.75)$ \\
\cline { 2 - 7 } & 3-day lag & $1.00(0.53-1.91)$ & $0.57(0.23-1.40)$ & $1.76(0.74-4.18)$ & $0.92(0.45-1.87)$ & $3.23(1.05-9.95)$ \\
\hline With AR & 0-day lag & $1.57(0.94-2.65)$ & $0.84(0.40-1.75)$ & $1.01(0.52-1.95)$ & $1.38(0.75-2.54)$ & $0.60(0.29-1.26)$ \\
\cline { 2 - 6 }$(N=245)$ & 1-day lag & $1.34(0.79-2.29)$ & $0.74(0.37-1.50)$ & $0.87(0.44-1.71)$ & $1.44(0.77-2.69)$ & $0.84(0.40-1.77)$ \\
\cline { 2 - 6 } & 2-day lag & $1.08(0.63-1.84)$ & $1.97(1.02-3.80)$ & $0.82(0.41-1.64)$ & $1.63(0.84-3.17)$ & $0.83(0.40-1.72)$ \\
\cline { 2 - 6 } & 3-day lag & $1.52(0.89-2.59)$ & $0.97(0.47-1.99)$ & $1.14(0.56-2.32)$ & $2.38(1.17-4.84)$ & $0.96(0.46-2.02)$ \\
\hline
\end{tabular}

$\mathrm{NO}_{2}$ - nitrogen dioxide, $\mathrm{SO}_{2}$ - sulphur dioxide, $P M_{25}$ - particulate matter with an aerodynamic diameter of $2.5 \mu m$ or less, $P M_{10}-$ particulate matter with an aerodynamic diameter of $10 \mu \mathrm{m}$ or less, $B C$ - black carbon, $A R$ - allergic rhinitis. Odds ratios were calculated for the third quintile of selected air pollutants and were adjusted for temperature, humidity and air pressure on the same day. Referent value for $\mathrm{PM}_{2.5}$ and $\mathrm{BC}$ was first quintile, while referent value for $\mathrm{NO}_{2}$, $\mathrm{SO}_{2}$ and $P M_{10}$ was fifth quintile. All significant values are in bold.

BC. We found that concentration of BC in the third quintile increased the risk for asthma exacerbation on lag-3, for more than three times (OR=3.23; 95\% Cl: 1.05-9.95). The large concentration of $\mathrm{BC}$ that exceeds permitted daily limit values, in the Užice region, is a result of household heating during the cold season because most of the heating houses use coal or oil. Previous studies have reported positive associations between $B C$ and ED visits and hospital admissions for asthma [22-24].

$\mathrm{PM}_{10}$ is one of the top air pollutants in Serbia, with all air quality monitoring stations in the country registering exceedances of the permitted daily limit value of $50 \mu$ g per cubic meter $\left(\mu \mathrm{g} / \mathrm{m}^{3}\right)$ [25]. We observed a significant association between 3-day lag exposure to $\mathrm{PM}_{10}$ and $E D$ visits for asthma with coexisting $A R(O R=2.38$; 95\% Cl: 1.17-4.84), which is in accordance with most previous studies of short-term health effects [26-31].
In contrast, several other studies have failed to observe a statistically significant association [24, 32, 33].

According to a large systematic review and metaanalysis of 110 peer-reviewed time series studies, Atkinson et al. [6] pointed to adverse associations between short-term exposure to daily concentrations of $\mathrm{PM}_{25}$ and daily mortality and hospital admissions for cardiovascular and respiratory diseases. Zheng et al. [30] and Orellano et al. [34] in their systematic reviews and meta-analyses of 87 and 22 studies respectively, found a significant association between exposure to $\mathrm{PM}_{2.5}$ and asthma exacerbations. However we failed to find any statistically significant association between $\mathrm{PM}_{2.5}$ and asthma ED visits, which is in accordance with a Canadian study conducted by Lavigne et al. [35].

In this study we found a positive association between exposure to $\mathrm{NO}_{2}$, one of the main air pollutants which is 
typically associated with vehicle emissions, and ED visits for asthma with coexisting AR $(\mathrm{OR}=1.57$; $95 \% \mathrm{Cl}$ : 0.942.65). The harmful effects of $\mathrm{NO}_{2}$ exposure on asthma exacerbation were reported by several studies [12, 22, 24, 28, 33, 34, 36]. Modig et al. [37] found a positive association between asthma onset (OR per $10 \mu \mathrm{g} / \mathrm{m}^{3} 1.46,95 \% \mathrm{Cl}$ : 1.07-1.99) and incident asthma in adults (OR per $10 \mu \mathrm{g} / \mathrm{m}^{3}$ $1.54,95 \% \mathrm{Cl}: 1.00-2.36)$ and the levels of $\mathrm{NO}_{2}$, which remained statistically significant after adjusting for potential confounders. Several authors [22, 31] found a strong correlation between emergency admissions for asthma and $\mathrm{NO}_{2}$ level only during cold seasons. Zheng et al. [30] in the meta-analysis of 87 time-series studies (including casecrossover studies) of short-term exposure to air pollutants, found that $\mathrm{NO}_{2}$ was associated with significantly increased risks of asthma emergency room visits and hospitalizations ( $R R=1.02 ; 95 \% \mathrm{Cl}: 1.01-1.02)$. Based on results from 26 studies, Zhang et al. [38] found a statistically significant association between $\mathrm{NO}_{2}$ and asthma emergency hospital admissions only in children but not in people aged 15-64.

According to our results, a 2-day lag exposure to $\mathrm{SO}_{2}$ was associated with asthma exacerbation (OR = 1.97; 95\% Cl: 1.02-3.80), which is in accordance with previous studies on adults and children [24, 27, 30, 31, 39], while other authors have failed to observe such associations $[25,33]$. Gharehchahi et al. [40] found a positive relationship between concentration of $\mathrm{SO}_{2}$ and hospital admissions due to respiratory diseases in the elderly, while Galán et al. [29] did not find any relationship between $\mathrm{SO}_{2}$ and asthma emergency room admissions.

There are several strengths of the present study. This manuscript is unique in that it is a novel population studied. Further, the time-stratified case-crossover design in which cases serve as their own control, used in the present study, has been demonstrated as a suitable method for assessing the relationship between air pollution and asthma exacerbation. Also, the reported odds ratios have been adjusted for the possible confounding influence of weather variables. However, there are several methodological limitations. The first one is that the study lacks statistical power to properly evaluate potential sex and age differences and some of non-statistically-significant associations reported (e.g. for $\mathrm{PM}_{2.5}$ ). The second one is due to the fact that the regional measures of air pollution from fixed-site monitoring stations were taken as the measure of exposure to air pollutants for each individual in this study. The third one is that we did not adjust for the confounding influence of levels of aeroallergens, which could lead to a change in risk.

\section{Conclusions}

Taking into consideration all limitations, our study confirms the association between exposure to $P M_{10}, B C$, $\mathrm{NO}_{2}$, and $\mathrm{SO}_{2}$ pollutants and $\mathrm{ED}$ visits for allergic asthma in the Užice region, Serbia. Considering the importance of the geographical location of the study area as a combination of an industrial region and climatic health resort suitable for the treatment of respiratory diseases, the analysis of the short-term effect of outdoor air pollutants to allergic asthma in the Užice region is of great public health importance in establishing relevant public policy in western Serbia. Since most inhabitants in Užice, Kosjerić, and Sevojno use coal for heating, the introduction of a gas pipeline would reduce the concentration of combustion pollutants such as $\mathrm{BC}$ and $\mathrm{SO}_{2}$, which could decrease the number of asthma exacerbations. According to WHO recommendations [5], particulate air pollution can be reduced using stricter air quality standards and limits for emissions from various sources, reducing energy consumption, especially that based on combustion sources, changing modes of transport, land use planning, as well as individual behavioural changes (e.g. using cleaner modes of transport and household energy sources). Reasonable efforts to reduce ambient pollution levels and aeroallergen exposures offer the expectation to reduce asthma morbidity and asthma exacerbation in the Užice region.

\section{Acknowledgments}

This work was supported by the Ministry of Education, Science and Technological Development of the Republic of Serbia (project No. 175025).

\section{Conflict of interest}

The authors declare no conflict of interest.

\section{References}

1. Elliot AJ, Smith S, Dobney A, et al. Monitoring the effect of air pollution episodes on health care consultations and ambulance call-outs in England during March/April 2014: a retrospective observational analysis. Environ Pollut 2016; 14: 903-11.

2. Weber SA, Insaf TZ, Hall ES, et al. Assessing the impact of fine particulate matter (PM 2.5) on respiratory-cardiovascular chronic diseases in the New York City Metropolitan area using Hierarchical Bayesian Model estimates. Environ Res 2016; 151: 399-409.

3. Xu Q, Li X, Wang S, et al. Fine particulate air pollution and hospital emergency room visits for respiratory disease in urban areas in Beijing, China, in 2013. PLoS One 2016; 11: e0153099.

4. European Environment Agency. Air quality in Europe 2018 report. EEA, Copenhagen, Denmark. Available from https:// www.eea.europa.eu/publications/air-quality-in-europe-2018.

5. WHO. Health effects of particulate matter. Policy implications for countries in eastern Europe, Caucasus and central Asia. Copenhagen: World Health Organization Regional Office for Europe, 2013. Available from http://www.euro.who. int/_data/assets/pdf_file/0006/189051/Health-effects-ofparticulate-matter-final-Eng.pdf

6. Atkinson RW, Kang S, Anderson HR, et al. Epidemiological time series studies of PM2.5 and daily mortality and hospital 
admissions: a systematic review and meta-analysis. Thorax 2014; 69: 660-5.

7. Tomic Spiric V, Jankovic S, Jovic Vranes A, et al. The impact of air pollution on chronic respiratory diseases. Pol J Environ Stud 2012; 21: 481-90.

8. Weinmayr G, Romeo E, De Sario M, et al. Short-term effects of PM10 and NO2 on respiratory health among children with asthma or asthma-like symptoms: a systematic review and meta-analysis. Environ Health Perspect 2010; 118: 449-57.

9. Li J, Sun S, Tang R, et al. Major air pollutants and risk of COPD exacerbations: a systematic review and meta-analysis. Int J Chron Obstruct Pulmon Dis 2016; 11: 3079-91.

10. Schildcrout JS, Sheppard L, Lumley T, et al. Ambient air pollution and asthma exacerbations in children: an eight-city analysis. Am J Epidemiol 2006; 164: 505-17.

11. Samoli E, Nastos PT, Paliatsos AG, et al. Acute effects of air pollution on pediatric asthma exacerbation: evidence of association and effect modification. Environ Res 2011; 111: 418-24.

12. Altzibar JM, Tamayo-Uria I, De Castro V, et al. Epidemiology of asthma exacerbations and their relation with environmental factors in the Basque Country. Clin Exp Allergy 2015; 45: 1099-108.

13. Leung TF, Ko FW, Wong GW. Roles of pollution in the prevalence and exacerbations of allergic diseases in Asia. J Allergy Clin Immunol 2012; 129: $42-7$.

14. Lee SY, Chang YS, Cho SH. Allergic diseases and air pollution. Asia Pac Allergy 2013; 3: 145-54.

15. Stevanović I, Jovašević-Stojanović M, Jović Stošić J. Association between ambient air pollution, meteorological conditions and exacerbations of asthma and chronic obstructive pulmonary disease in adult citizens of the town of Smederevo. Vojnosanit Pregl 2016; 73: 152-8.

16. Stanković A, Nikolić M. Long-term ambient air pollution exposure and risk of high blood pressure among citizens in Nis, Serbia. Clin Exp Hypertens 2016; 38: 119-24.

17. Census of Population, Households and Dwellings in the Re public of Serbia 2011: Comparative Overview of the Number of Population in 1948, 1953, 1961, 1971, 1981, 1991, 2002 and 2011, Data by settlements. Statistical Office of Republic of Serbia, Belgrade 2014. p. 178.

18. National network of automatic stations for air quality monitoring. Available from http://www.amskv.sepa.gov. $\mathrm{rs} /$ ?lng=en

19. WHO. Air Quality Guidelines. Global Update 2005. Copenhagen: World Health Organization Regional Office for Europe, 2006. Available from http://www.euro.who.int/ data/assets/pdf_file/0005/78638/E90038.pdf

20. WHO. Health Relevance of Particulate Matter from Various Sources. Report on a WHO Workshop. Copenhagen: World Health Organization Regional Office for Europe, 2007. Available from http://www.euro.who.int/_data/assets/pdf file/0007/78658/E90672.pdf

21. Olstrup H, Johansson C, Forsberg B. The use of carbonaceous particle exposure metrics in health impact calculations. Int J Environ Res Public Health 2016; 13: E249.

22. Castellsague J, Sunyer J, Sáez M, Antó JM. Short-term association between air pollution and emergency room visits for asthma in Barcelona. Thorax 1995; 50: 1051-6.

23. Walters S, Griffiths RK, Ayres JG. Temporal association between hospital admissions for asthma in Birmingham and ambient levels of sulphur dioxide and smoke. Thorax 1994; 49: 133-40.
24. Sunyer J, Spix C, Quénel P, et al. Urban air pollution and emergency admissions for asthma in four European cities: the APHEA Project. Thorax 1997; 52: 760-5.

25. Serbian Environmental protection Agency (SEPA). Annual Report on the Environment: Excessive air pollution registered in Belgrade, other Serbian cities in 2017. Available from https://balkangreenenergynews.com/sepa-report-excessive-air-pollution-registered-in-belgrade-other-serbiancities-in-2017/

26. Schwartz J, Slater D, Larson TV, et al. Particulate air pollution and hospital emergency room visits for asthma in Seattle. Am Rev Respir Dis 1993; 147: 826-31.

27. Rossi OV, Kinnula VL, Tienari J, Huhti E. Association of severe asthma attacks with weather, pollen, and air pollution. Thorax 1993; 48: 244-8.

28. Atkinson RW, Anderson HR, Strachan DP, et al. Short-term associations between outdoor air pollution and visits to accident and emergency departments in London for respiratory complaints. Eur Respir J 1999; 13: 257-65.

29. Galán I, Tobías A, Banegas JR, Aránguez E. Short-term effects of air pollution on daily asthma emergency room admissions. Eur Respir J 2003; 22: 802-8.

30. Zheng XY, Ding H, Jiang LN, et al. Association between air pollutants and asthma emergency room visits and hospital admissions in time series studies: a systematic review and meta-analysis. PLoS One 2015; 10: e0138146.

31. Moghtaderi M, Zarei M, Farjadian S, Shamsizadeh S. Prediction of the impact of air pollution on rates of hospitalization for asthma in Shiraz based on air pollution indices in 20072012. Open J Air Pollution 2016; 5: 37-43.

32. Chen L, Omaye ST. Air pollution and health effects in Northern Nevada. Rev Environ Health 2001; 16: 133-49.

33. Tenias JM, Ballester F, Rivera ML. Association between hospital emergency visits for asthma and air pollution in Valencia, Spain. Occup Environ Med 1998; 55: 541-7.

34. Orellano P, Quaranta N, Reynoso J, et al. Effects of outdoor air pollution on asthma exacerbations in children and adults: systemic review and multilevel meta-analysis. PLoS One 2017; 12: e0174050.

35. Lavigne E, Villeneuve PJ, Cakmak S. Air pollution and emergency department visits for asthma in Windsor, Canada. Can J Public Health 2012; 103: 4-8.

36. Simpson R, Williams G, Petroeschevsky A, et al. The shortterm effects of air pollution on hospital admissions in four Australian cities. Aust N Z J Public Health 2005; 29: 213-21.

37. Modig L, Torén K, Janson C, et al. Vehicle exhaust outside the home and onset of asthma among adults. Eur Respir J 2009; 33: 1261-7.

38. Zhang S, Li G, Tian L, et al. Short-term exposure to air pollution and morbidity of COPD and asthma in East Asian area: a systematic review and meta-analysis. Environ Res 2016; 148: 15-23.

39. Bates DV, Baker-Anderson M, Sizto R. Asthma attack periodicity: a study of hospital emergency visits in Vancouver. Environ Res 1990; 51: 51-70.

40. Gharehchahi E, Mahvi AH, Amini H, et al. Health impact assessment of air pollution in Shiraz, Iran a two-part study. J Environ Health Sci Eng 2013; 11: 11. 